\title{
The Effects of Classifying CRM Sources on the Asphalt Cement Modification for Paving Roads
}

\author{
Forat Y. Al-Jaberi (Corresponding author) \\ Chemical Engineering Department, Basrah University, Iraq \\ E-mail: Furat_Yasir@yahoo.com
}

Abdul-Wahab A. Sultan

Petrochemical Engineering Department, Basrah Technical College, Iraq

E-mail: Dr.wahab57@gmail.com

Adnan A. Ateeq

Petrochemical Engineering Department, Basrah Technical College, Iraq

E-mail: Adnan_ateeq@yahoo.com

Received: August 16, 2013 Accepted: September 5, 2013 Published: October 25, 2013

doi:10.5296/jee.v4i2.4461 URL: http://dx.doi.org/10.5296/jee.v4i2.4461

\begin{abstract}
The improvement of Basrah asphalt cement that used in hot mix pavement can be achieved by using four influencing variables, which are the value of temperature needed for mixing, time of mixing, the amount of wasted car tire rubber (WCR) and the amount of wasted truck tire rubber (WTR). The main virtue of this study is to know the affecting of classifying the CRM sources, and how that will enhance the properties of tire rubber modified asphalt binder. The improvement is estimated through using the ranges $\left(150-180{ }^{\circ} \mathrm{C}\right)$ of temperature, $(20-60)$ minute of mixing time, (10-20) gm of WCR and (0-4) gm of WTR.

The using of two different types of waste tires had shown clearly the affecting on the results of responses studied. The effect of independent variables was studied by using Box-Wilson technique of experimental design. Moreover, the regression coefficients for responses models equation and the optimum conditions were estimated by using STATISTICA software.

The results had shown that the optimum values of the independent variables to submit the
\end{abstract}




\section{Macrothink}

best responses of penetration test and softening point test was at temperature $\left(180^{\circ} \mathrm{C}\right)$, mixing time (60 minute), WCR (20 gm), and WTR (4gm) and then found new mathematical models to estimate these responses at any values of independent variables. The Marshall stability result of the modified asphalt mixes was higher than of the unmodified asphalt mixes.

Keywords: Wasted car tires rubber WCR, Wasted truck tires rubber WTR, Asphalt cement AC, Preparation 


\section{Introduction}

Millions of new tires are produced annually around the world according to the Tire Business Statistics (Michelin Fact Book) and this number increases every year according to wide needs for transportation vehicles, cars or trucks, in addition to other usages of tires. One scrap tire per one person was generated (Heitzman, 1992) according to the US studies which refers to the large number of waste tires that may reach approximately 900 million scrap tires every world wide (Way, G.B. et al. 2011).

Hence, millions of scrap tires become available for reprocessing into crumb rubber as an environmentally economical sound method of waste tires reduction (Carlson et al.1999). It is delivered to rubber processing plants either as whole tires, cut tires (tread and sidewalls), or shredded tires which are further reduced in size by ambient or cryogenic grinding of crumb rubber to produce crumb rubber, the steel belting and fiber reinforcing are separated and removed. Crumb rubber cannot be considered as a waste material, it is proved that it is one of the only modifiers to pavement of roads derived from a waste material by recycling of scraped tires.

The proportion of the elastomer (natural and synthetic rubber (Caltrans ,2006)) varies according to the size and the use of the tire, cars or trucks, but in general the truck tire rubber contain larger percentage of natural rubber compared to that in car tire rubber (Williamson , 2006). In the present study, Basrah refinery asphalt cement is used.

Up till now, more of studies that used CRM as an additive for modifying asphalt cement (AC) without any classifying of CRM sources, wasted cars tires rubber or wasted trucks tires rubber, are: Abass et al., 2009, Aisien et al., 2006, Bahia et al., 2011, Carlson et al., 1999, Coomarasamy et al.,1997, Engle et al., 2002, Fayadh,S.S., 1987, Fonts et al., 2009, Ghaly,N.F., et al., 2008, Heitzman.M.A., 1992, Kumar et al., 2009, Neto et al., 2009, Papaiannakis et al., 1995, Pavlovich et al., 1978, Sousa et al., 2000, Williamson.P., 2006, Khodary.F, 2010. The present study aimed at investigating the benefit classification of CRM sources on the asphalt cement modification for roads pavement requirements.

\section{Experimental Details}

\subsection{Experimental Apparatuses}

The apparatuses that used in the present study to achieve the required results of using the classified CRM according to sources, as a benefit modifier are:

- Mixer apparatus consist of oil bath (model LABTECH / Malaysia, model LOB-511D), Mechanical stirrer type ANALIS / Belgium, Thermometer model QUICKFIT Corning / England, model MF32-C7/250 with a range of temperature is $\left(0-250^{\circ} \mathrm{C}\right)$, and Stainless steel containers.

- $\quad$ Penetration test apparatus (model ZHEJIANG TUGONG Instrument Co. /Japan, Serial No. 09108).

- $\quad$ Softening point apparatus (model TECHNOVERTO company) 
- Electronic balance apparatus (model ADEM-USA).

- Water bath apparatus (model FREUNDL -Germany).

- Compactor apparatus (model VIATEST - EOH-Germany).

- Marshall (stability and flow) apparatus (model ELE international - England).

\subsection{Specimen Preparation}

The main materials that had been used in the current study are:

- Waste rubber had taken from disposal car tires WCR.

- Waste rubber had taken from disposal truck tires WTR.

The size of waste rubber used in the present study has to be finally ground equal or less than sieve No. 30 ( specified sieve opening is 0.0232 inch or $0.6 \mathrm{~mm})^{(6,35,36,40)}$ that some times called one size fine grading. The less difference in the size of waste rubber is refers to the difference in compositions ratios especially the actual and synthetic kinds of rubber in the recycled tire. The use of this finally size of rougher waste rubber will swell quicker and easily to absorb the asphalt cement.

- Aggregates that used are uniform quality and crushed to the size of coarse portion ranges from sieve $(19.0 \mathrm{~mm})$ to sieve $(4.75 \mathrm{~mm})$, while middle and fine portion of aggregates ranges between sieves $(4.75 \mathrm{~mm})$ to $(0.075 \mathrm{~mm})$. The reason of using crushed aggregates in the surface course is the mechanical interaction between the aggregates and the increment of the resistance to shoving because of the fraction action that increased between the coarser aggregates that all would lead to the high stability required.

- Mineral Filler that can be used according to ASTM-D242/ 2003 or AASHTO-M17/2010 .Where this additive physically increases the viscosity of asphalt cement to a limited range, which leads to more stability of the pavement layer and decreasing the effects of high ambient temperatures. This filler cans also decreasing the bleeding of excess asphalt cement used by absorbing this excess portion and then decreasing the porosity of the final pavement surface.

- Asphalt Cement that applied in the present study is supplied from Basrah refinery with the following specifications, which listed in Table (1) according to the specification of ASTM and AASHTO.

Table (1). Physical properties of asphalt cement selected

\begin{tabular}{|l|l|l|l|}
\hline The Property & Unit & Test & Value \\
\hline Specific gravity at $25{ }^{\circ} \mathrm{C}$ & $\mathrm{gm} / \mathrm{cm}^{3}$ & $\begin{array}{l}\text { ASTM-D-70 } \\
\text { AASHTO-T-228 }\end{array}$ & 1.03 \\
\hline Flash point & ${ }^{\circ} \mathrm{C}$ & $\begin{array}{l}\text { ASTM-D-92 } \\
\text { AASHTO-T-73 }\end{array}$ & 275 \\
\hline Penetration at $25^{\circ} \mathrm{C}$ & $1 / 10 \mathrm{~mm}$ & ASTM-D-5 & 46 \\
\hline
\end{tabular}




\begin{tabular}{|l|l|l|l|}
\hline$(100 \mathrm{gm}, 5 \mathrm{sec}, 0.1 \mathrm{~mm})$ & & AASHTO-T-49 & \\
\hline Softening point (ring and ball) & ${ }^{\circ} \mathrm{C}$ & $\begin{array}{l}\text { ASTM-D-36 } \\
\text { AASHTO-T-53 }\end{array}$ & 48 \\
\hline Solubility in $\mathrm{CCl}_{4} \%$ wt. min. & $\%$ & AASHTO-T-44 & 99 \\
\hline
\end{tabular}

The sequences of the experimental work can be summarized as follow:

- Preparing two enough amounts of the CRM according to the source of rubber which type wasted car tire car WCR and wasted truck tire WTR.

- Heating a limited amount of asphalt cement by using the oil bath in the Mixer apparatus until it reaches the restricted temperature then adding the restricted amounts of WCR and WTR, then keep mixing it for the limited known mixing time.

- Filling required measurement tools by limited amounts of the modified asphalt cement.

- Measuring the penetration responses, softening point responses, and Marshall properties (stability and flow).

\section{Results and Discussion}

\subsection{The Mathematical Models}

The coefficients of the second order polynomial will be estimated by using STATISTICA program according to the regression analysis rule for each of the responses that had been estimated experimentally. To emphasis the accuracy of the calculations, all the regression coefficients will be statistically, significant which means it will be estimated. The following models that estimated by using the non-linear estimation order are explained the relation between the response and the independent variables. Moreover, the temperature designed as $\mathrm{X}_{1}$, mixing time designed as $\mathrm{X}_{2}$, WCR designed as $\mathrm{X}_{3}$ and WTR designed as $\mathrm{X}_{4}$.

$$
\begin{aligned}
Y_{\text {Penetration }}= & 432.983-4.947 \mathrm{X}_{1}-0.387 \mathrm{X}_{2}-1.220 \mathrm{X}_{3}-0.183 \mathrm{X}_{4}+0.016 \mathrm{X}_{1}^{2}+0.003 \mathrm{X}_{2}^{2} \\
& +0.041 \mathrm{X}_{3}^{2}+0.754 \mathrm{X}_{4}^{2}+2.703 \times 10^{-9} \mathrm{X}_{1} \mathrm{X}_{2}-0.007 \mathrm{X}_{1} \mathrm{X}_{3}+0.017 \mathrm{X}_{1} \mathrm{X}_{4}+0.025 \\
& \mathrm{X}_{2} \mathrm{X}_{3}-0.088 \mathrm{X}_{2} \mathrm{X}_{4}-0.100 \mathrm{X}_{3} \mathrm{X}_{4}
\end{aligned}
$$

The proportion of variance for the penetration was equal to $(0.97764)$ and the correlation coefficient $(\mathrm{R})$ was $(0.98870)$, so the number of iterations will be terminated.

$$
\begin{aligned}
\mathrm{G}_{\text {Softening point }} & =150.2499-0.7667 \mathrm{X}_{1^{-}} 0.1833 \mathrm{X}_{2}-1.3333 \mathrm{X}_{3}-22.0833 \mathrm{X}_{4}+0.0011 \mathrm{X}_{1}^{2}- \\
& 0.0031 \mathrm{X}_{2}^{2}+0.0300 \mathrm{X}_{3}^{2}+0.563 \mathrm{X}_{4}^{2}+0.0033 \mathrm{X}_{1} \mathrm{X}_{2}+0.0067 \mathrm{X}_{1} \mathrm{X}_{3}+0.0833 \\
& \mathrm{X}_{1} \mathrm{X}_{4}-0.0100 \mathrm{X}_{2} \mathrm{X}_{3}+0.0250 \mathrm{X}_{2} \mathrm{X}_{4}+0.4500 \mathrm{X}_{3} \mathrm{X}_{4}
\end{aligned}
$$

The proportion of variance for the softening point response was equal to (0.96846) and the correlation coefficient $(\mathrm{R})$ was $(0.98411)$, so the number of iterations will be terminated.

\subsection{The Affecting of the Classified CRM on the Responses}

In simple comparison depending on the mathematical models, the effect of classifying CRM in to types, WCR and WTR, is very clear. Table (2) explains this positive affecting on responses when using of WCR only or incorporate with WTR at optimum temperature and mixing time. 
Table (2). The positive effect of using WTR for AC modification

\begin{tabular}{|c|c|c|c|}
\hline The variable & Unit & The value (case I) & The value (case II) \\
\hline Temperature & ${ }^{\circ} \mathrm{C}$ & 180 & 180 \\
\hline Time & min. & 60 & 60 \\
\hline WCR & gm & 20 & 16 \\
\hline WTR & gm & 0 & 4 \\
\hline Penetration & $\mathrm{mm}$ & 31.575 & 25.377 \\
\hline Softening point & ${ }^{\circ} \mathrm{C}$ & 58.820 & 72.860 \\
\hline
\end{tabular}

The following figures are shown the effects of CRM sources classification:

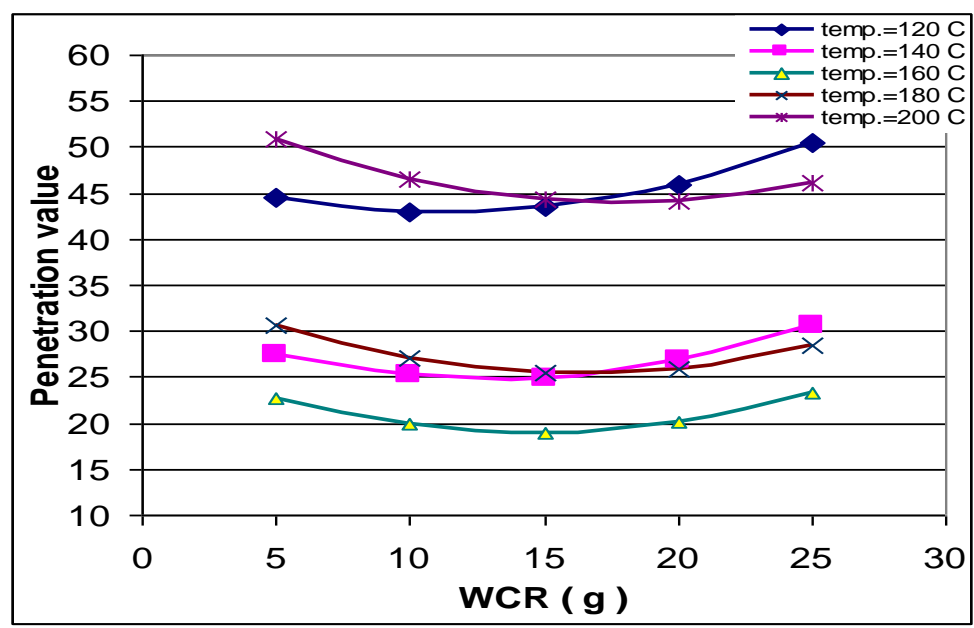

Figure (1). Penetration value as a function of WCR at optimum WTR \& mixing time and various temperatures

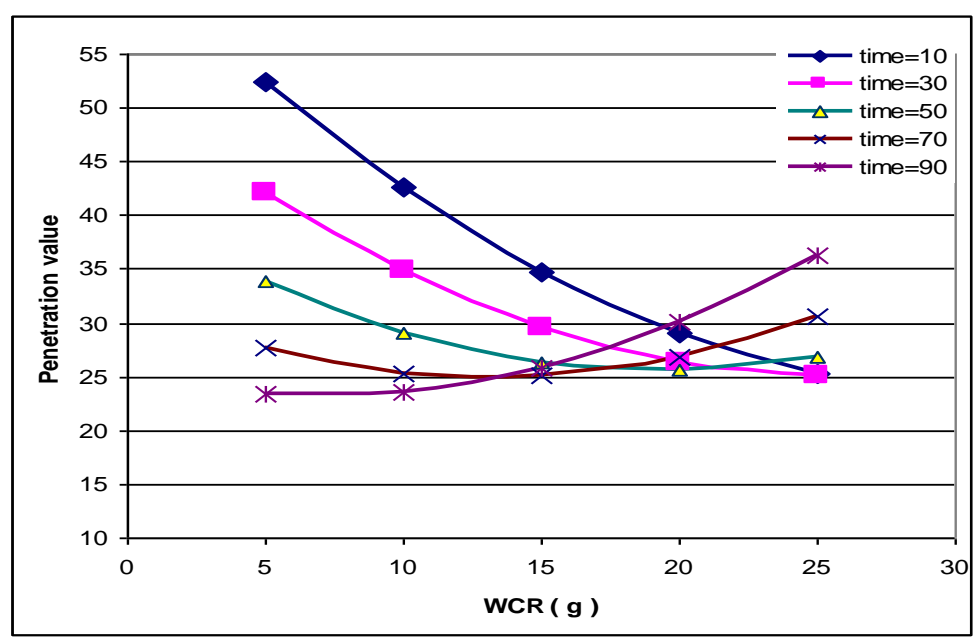

Figure (2). Penetration value as a function of WCR at optimum WTR \& temperature and various mixing time 


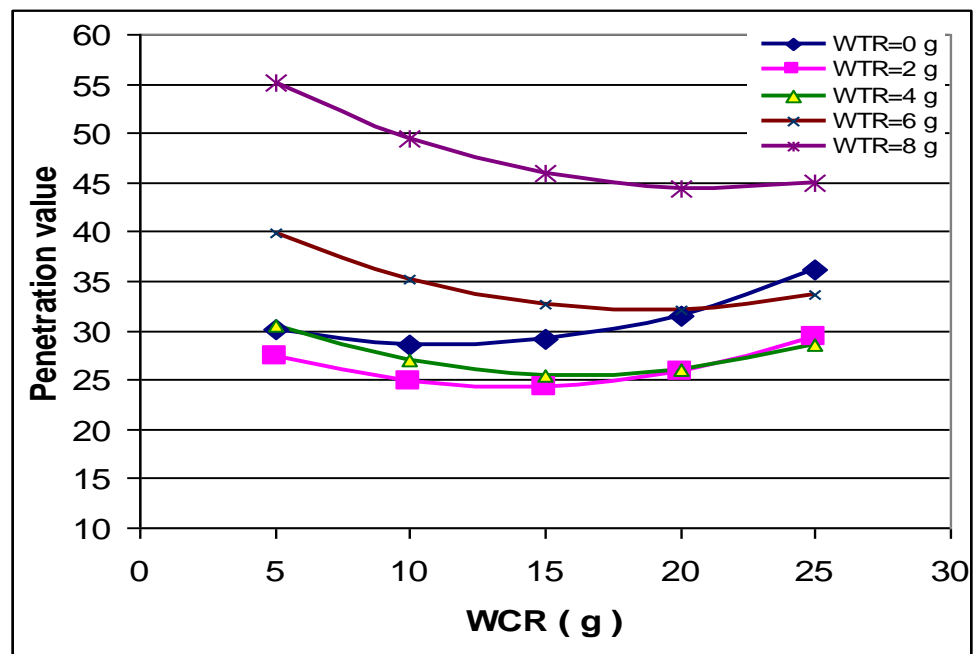

Figure (3). Penetration value as a function of WCR at optimum temperature \& mixing time and various WTR

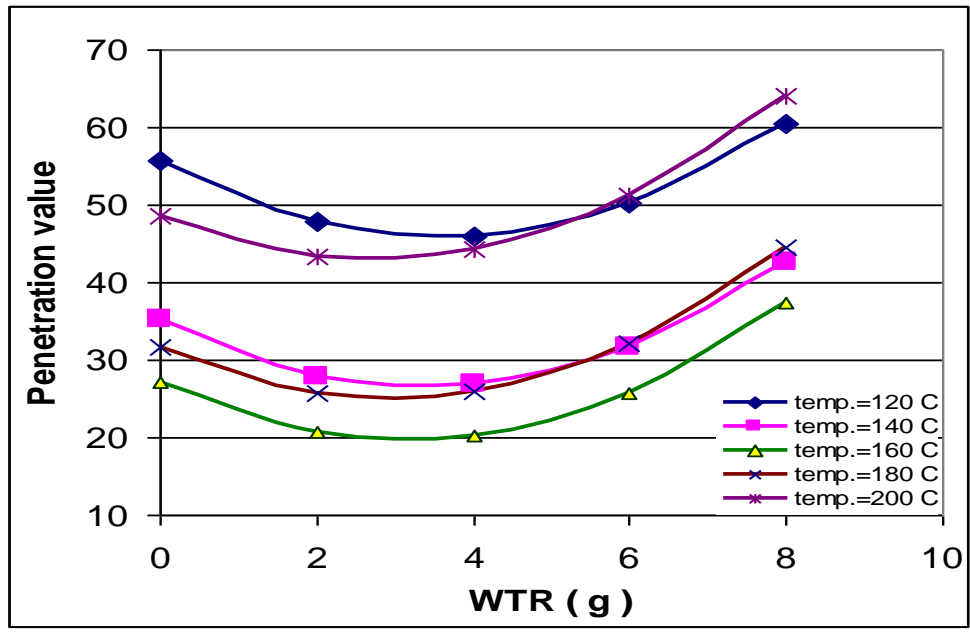

Figure (4). Penetration value as a function of WTR at optimum \& mixing time \& WTR and various temperatures 


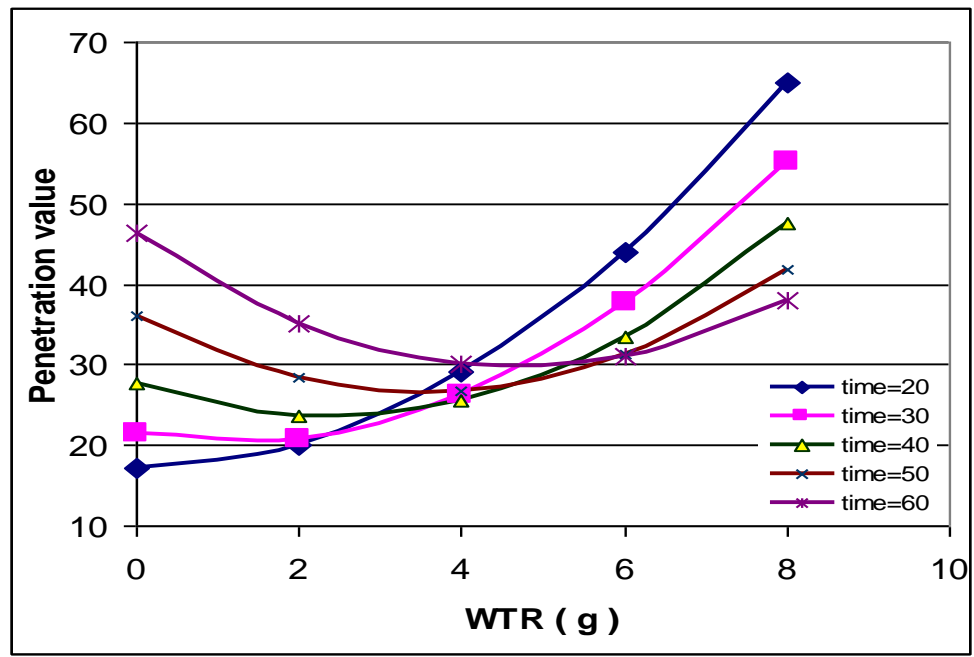

Figure (5). Penetration value as a function of WTR at optimum WCR \& temperature and various mixing time

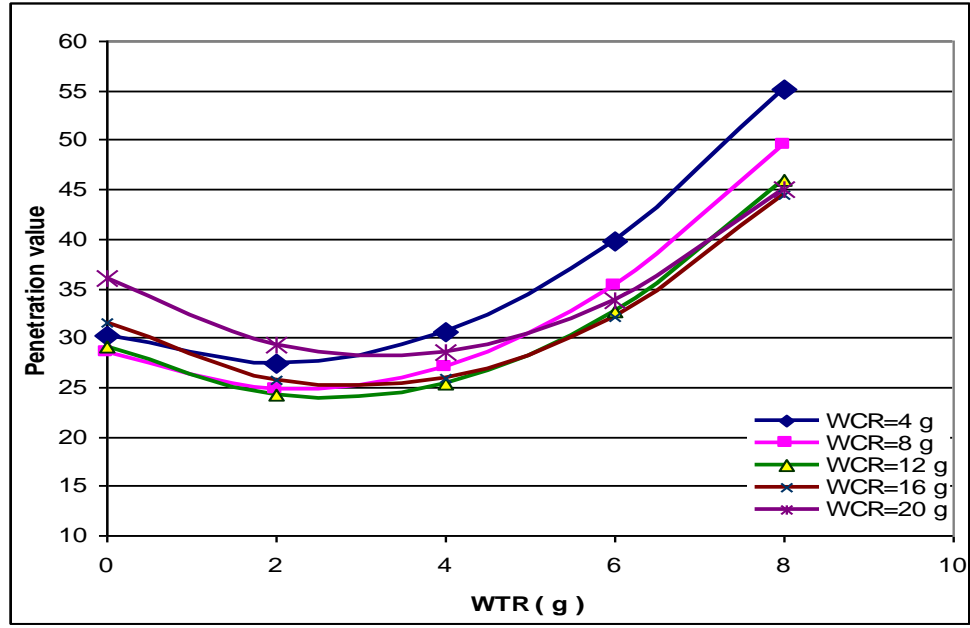

Figure (6). Penetration value as a function of WTR at optimum temperature \& mixing time and various WCR 


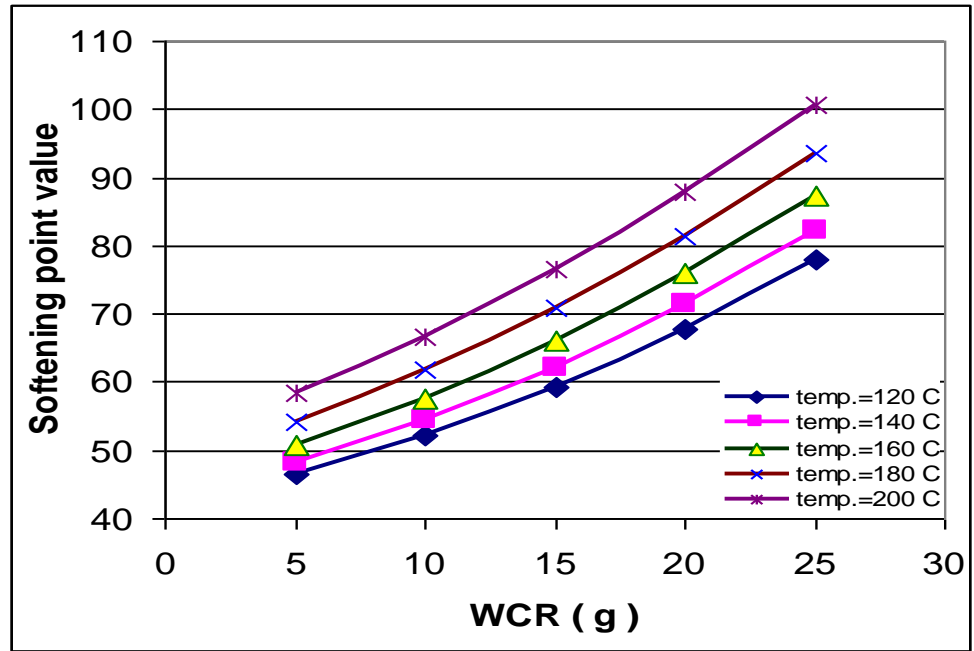

Figure (7). Softening point value as a function of WCR at optimum mixing time \& WTR and various temperatures

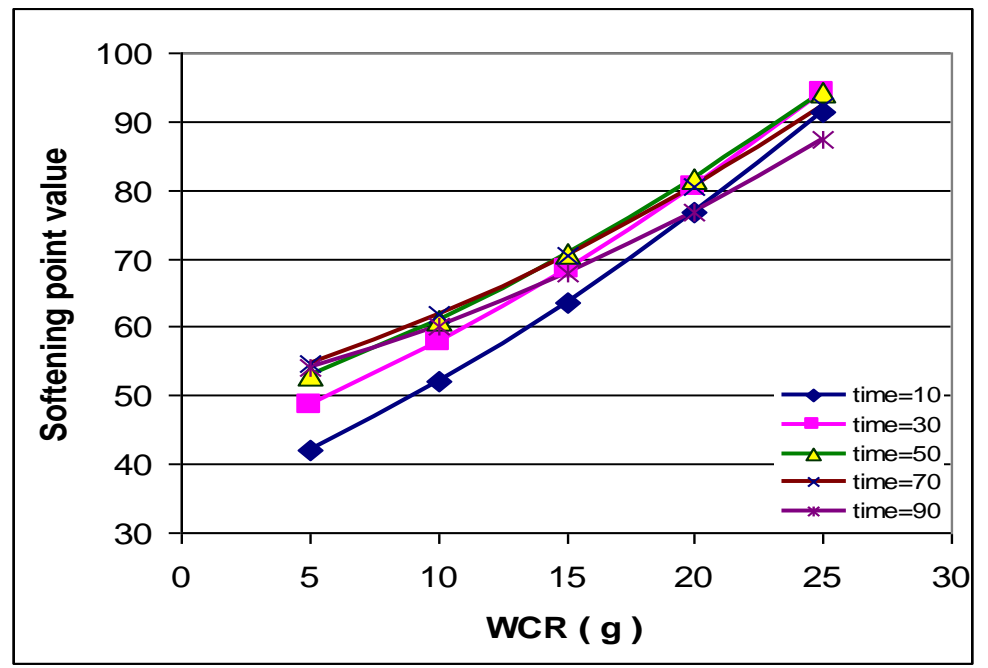

Figure (8). Softening point value as a function of WCR at optimum temperature \& WTR and various mixing time 


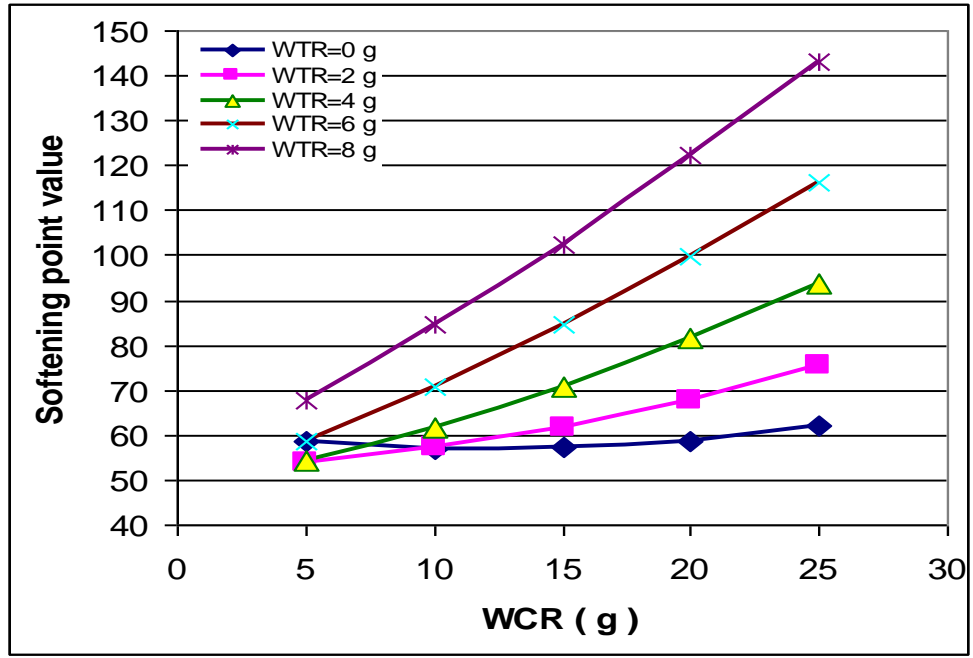

Figure (9). Softening point value as a function of WCR at optimum temperature \& mixing time and various WTR

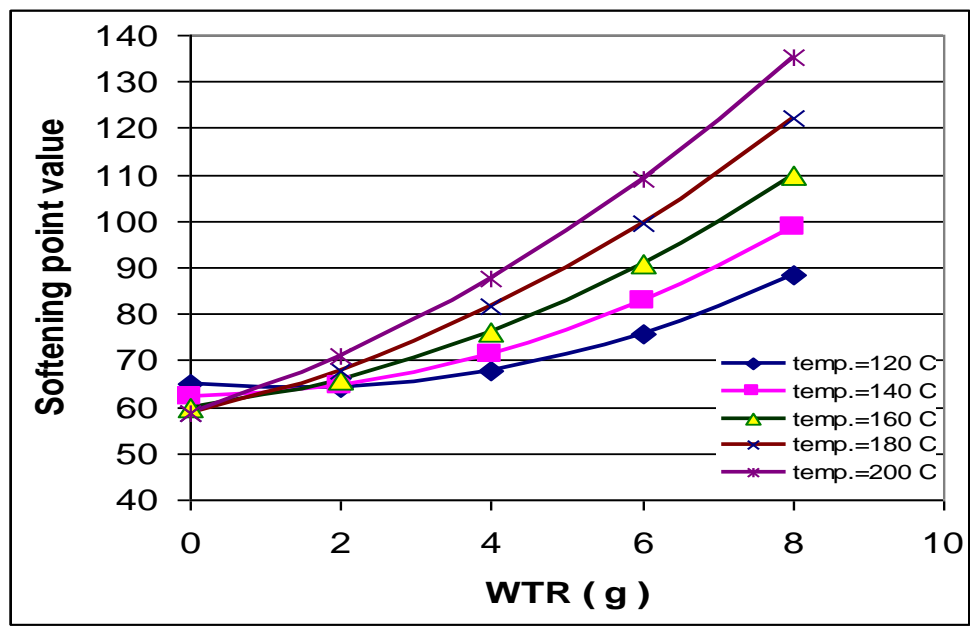

Figure (10). Softening point value as a function of WTR at optimum mixing time \& WCR and various temperatures 


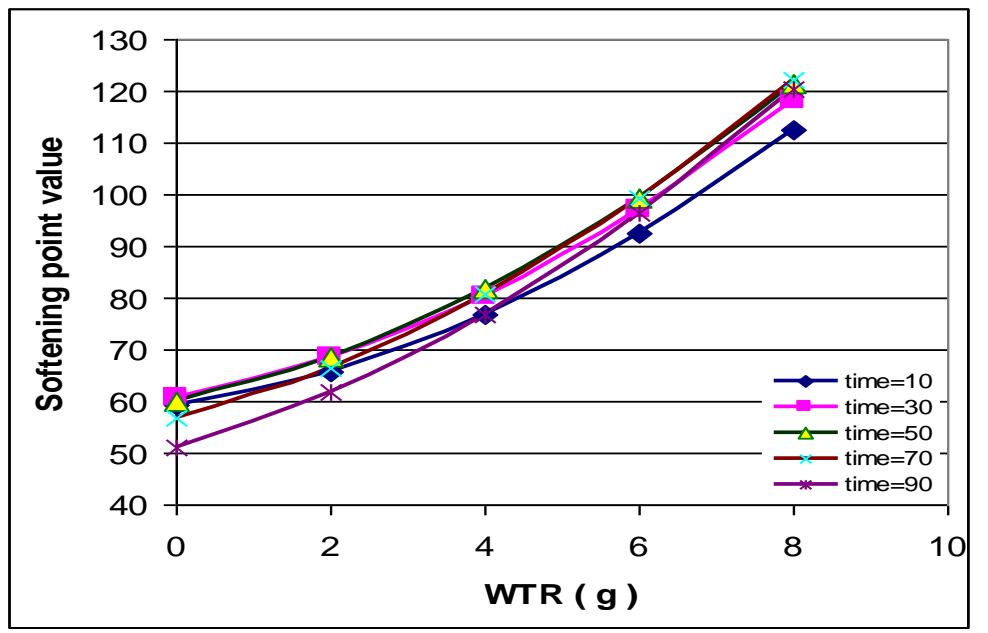

Figure (11). Softening point value as a function of WTR at optimum temperature \& WCR and various mixing time

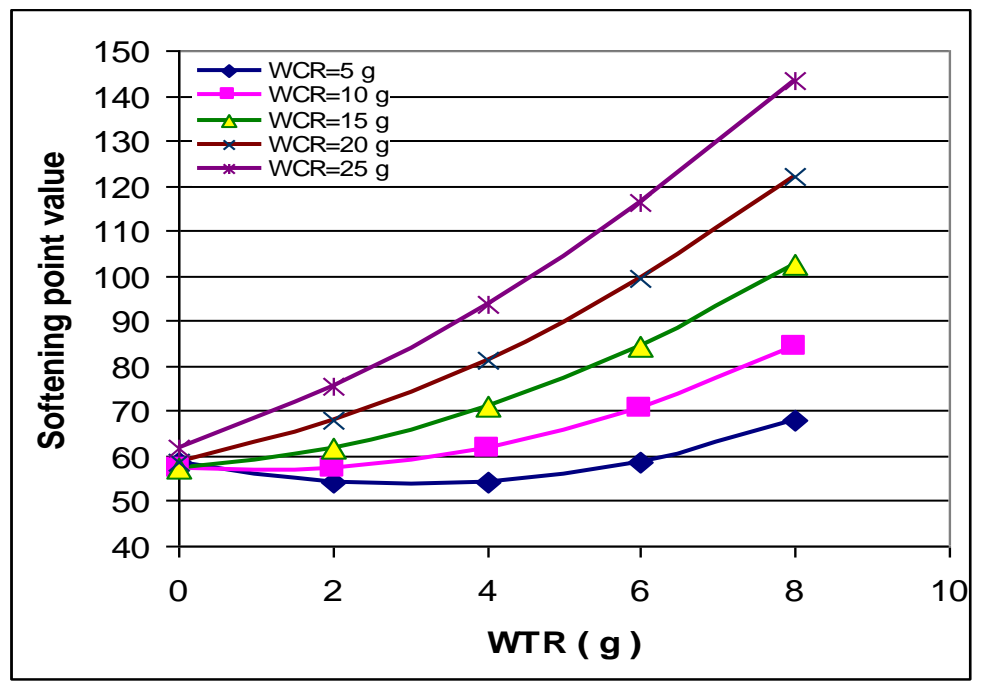

Figure (12). Softening point value as a function of WTR at optimum temperature \& mixing time and various WCR

\subsection{The Optimum Values}

The optimum values of the four variables that correspond to desired value of each one of responses can be determined by following one of the optimization techniques according to the analysis of central composite (response surface) via STATISTICA software. Table (3) is shown the values and differences of optimized independent variables and the critical values for each of responses respectively. 
Table (3). The optimum and critical values of the variables and their responses

\begin{tabular}{|c|c|c|c|c|c|}
\hline Variables & Unit & \multicolumn{2}{|c|}{ Penetration $(\mathrm{mm})$} & \multicolumn{2}{c|}{ Softening point $\left({ }^{\circ} \mathrm{C}\right)$} \\
\hline Case & & Optimum & Critical & Optimum & Critical \\
\hline Temperature & ${ }^{\circ} \mathrm{C}$ & 180 & 159.48 & 180 & 199.04 \\
\hline Time & min. & 60 & 61.20 & 60 & 68.24 \\
\hline WCR & $\mathrm{gm}$ & 20 & 12.64 & 20 & 6.89 \\
\hline WTR & $\mathrm{gm}$ & 4 & 2.75 & 4 & 0.61 \\
\hline Response's Value & --- & 25.933 & 17.786 & 81.471 & 55.611 \\
\hline
\end{tabular}

The Critical values were estimated via STATISTICA software display the information that identify the point on the quadratic response surface that defines the curvature of the surface, which give the lower values of responses than the values that estimated at low limits of independent variables, it give an attention when the operation must be stop.

\subsection{Results of Marshall Properties}

By using the following tests to the measurement of resistance to plastic flow asphalt mixtures using Marshall apparatus.

- $\quad$ ASTM D $1559-2003$

- $\quad$ AASHTO T $245-2010$

Table (4). Mechanical and physical properties of the specimens using different ratio of Modified Asphalt Cement $\boldsymbol{M A C}$

\begin{tabular}{|c|c|c|c|c|c|c|c|c|c|}
\hline $\begin{array}{c}\text { Modified } \\
\text { AC \%wt. }\end{array}$ & $\begin{array}{c}\text { Bulk } \\
\text { Volume }\end{array}$ & $F_{m 1}$ & $\begin{array}{c}\text { Bulk } \\
\text { Density }\end{array}$ & $\begin{array}{c}\text { Specific } \\
\text { Gravity }\end{array}$ & $\begin{array}{c}\text { VTM } \\
\%\end{array}$ & $\begin{array}{c}\text { VMA } \\
\%\end{array}$ & $\begin{array}{c}\text { VFA } \\
\%\end{array}$ & $\begin{array}{c}\text { Stability } \\
(\text { KN })\end{array}$ & $\begin{array}{c}\text { Flow } \\
m m\end{array}$ \\
\hline 4 & 511.333 & 1.000 & 2.290 & 2.488 & 7.954 & 16.849 & 52.805 & 13.230 & 3.233 \\
\hline 4.5 & 509.502 & 1.000 & 2.307 & 2.473 & 6.671 & 16.747 & 60.292 & 13.334 & 3.365 \\
\hline 5 & 507.667 & 1.040 & 2.320 & 2.452 & 5.388 & 16.645 & 67.780 & 13.433 & 3.500 \\
\hline 5.5 & 511.331 & 1.000 & 2.315 & 2.433 & 4.825 & 17.190 & 71.888 & 11.983 & 3.731 \\
\hline 6 & 515.000 & 1.000 & 2.314 & 2.417 & 4.264 & 17.734 & 75.995 & 10.532 & 3.967 \\
\hline
\end{tabular}

The properties of Hot Mix at the optimum value of modified asphalt cement (5.10\%) will be as shown in Table (5): 
Table (5). Hot Mix properties at the optimum value of Modified AC

\begin{tabular}{|c|c|c|c|c|c|c|}
\hline $\begin{array}{c}\text { Modified } \\
\mathrm{AC} \%\end{array}$ & Stability (KN) & $\begin{array}{c}\text { Flow } \\
(\mathrm{mm})\end{array}$ & $\begin{array}{c}\text { Bulk Density } \\
\left(\mathrm{gm} / \mathrm{cm}^{3}\right)\end{array}$ & VTM \% & VMA \% & VFA \% \\
\hline 5.10 & 13.30 & 3.60 & 2.320 & 5.20 & 16.70 & 68.00 \\
\hline $\begin{array}{c}\text { Specification } \\
\text { Limits }\end{array}$ & 8.00 minimum & $2-4$ & - & $3-7$ & - & - \\
\hline
\end{tabular}

While the Hot Mix properties for the same ratio but for non-modified asphalt cement, is explained in Table (6):

Table (6). Hot Mix properties at the optimum value of Non-Modified AC

\begin{tabular}{|c|c|c|c|c|c|c|}
\hline $\begin{array}{c}\text { Non-modified } \\
\text { AC } \%\end{array}$ & $\begin{array}{c}\text { Stability } \\
(\mathrm{KN})\end{array}$ & $\begin{array}{c}\text { Flow } \\
(\mathrm{mm})\end{array}$ & $\begin{array}{c}\text { Bulk Density } \\
\left(\mathrm{gm} / \mathrm{cm}^{3}\right)\end{array}$ & VTM \% & VMA \% & VFA \% \\
\hline 5.10 & 9.60 & 4.50 & 2.445 & 3.10 & 14.10 & 78.20 \\
\hline $\begin{array}{c}\text { Specification } \\
\text { Limits }\end{array}$ & $\begin{array}{c}8.00 \\
\text { minimum }\end{array}$ & $2-4$ & - & $3-7$ & - & - \\
\hline
\end{tabular}

Therefore, Table (5) consists of the important values that will be the most cost-effective and efficient solution for the process in addition to maximum requirements and yielding the best value of the performance criterion for several types of roads (expressway, national roads, and other).

\section{Conclusion}

The following conclusions can be drawn from the present investigation:

- The using of waste tires is more useful for the modification of asphalt cement that produced from Basrah refinery to be more efficient for the requirements of roads paving in various climatic and traffic condition according to standard quality performance. However, waster tires rubber is too cheap and consuming it in this way will be beneficial from the engineering, economic, and environmental points.

- The using of two types of waste tires, car and truck tires,(i.e. classification of CRM sources) will be more affecting on the results that noted in penetration, softening point, and then on Marshall properties.

- The using of WTR in the present study in a specified amount had been approved, that it is very effective and useful to enhance the properties of asphalt cement. Where there is, no previous research studied could classify the types of waste rubber to WCR and WTR to know the affecting of using that as the present study done.

- The elevation on all independent variables to limited ranges will be more useful in condition of stopping this elevation on the maximum ranges in this study (i.e. optimum values) and equal or more than the critical limits.

- Mathematical models had been found to be more useful in predicting the required 
responses where the using of STATISTICA software had increase the accuracy of estimating the parameters, critical and optimum values.

\section{References}

AASHTO standard. (2013). Specification and tests, methods of sampling and testing. Annual Book of American Association of State Highway and Transportation Officials, 311-350.

Abass, F. O., \& Abass, M. O. (2009). Optimization of asphalt mix improved by the addition of scrap tires. Eng \& Tech. Journal, 27(12), 2425-2446.

Abass,M. K. (1999). Absorption of No2 into water and dilute acid solutions in a fixed column. (M.Sc. Thesis), University of Baghdad, Iraq.

Abdalla, K. (2006). Health and environmental benefits of clean fuels and vehicles. Journal of health, Egypt, 45-62.

Ahmed, L. A. (2007). Improvement of Marshall properties of the asphalt concrete mixtures using the polyethylene as additive. College of Engineering, University of Basrah. Eng \& Tech, 25(3), 383-394.

Aisien, F. A., \& Hymore, F. K. (2006). Application of ground scrap tyre rubbers in asphalt concrete pavements. Indian Journal of Engineering and Materials Science, Nigeria, 13, 333-338.

Al Kateeb, G. G., \& Al Akhras, N. M. (2011). Properties of Portland cement-modified asphalt binder using superpave tests. Construction and building materials Journal, 25, 926-932. http://dx.doi.org/10.1016/j.conbuildmat.2010.06.091

AL Salami, M. N. (2011). Study of Basrah refinery asphalt modification by polymer addition for road paving uses. (M.Sc. Thesis), University of Basrah, Iraq.

Asphalt academy. (2007). The use of modified bituminous binders in road construction-Technical Guideline, 8-19.

Asphalt Rubber Technology Service (ARTS). (2012). Assessment of freeze-thaw durability of crumb rubber-modified Portland cement concrete. USA, 1-2.

ASTM Standard. (2013). 'Road and Paving Materials, Traveled surface Characteristics. Annual Book of American Society for Testing and Materials Standard, 403(4).

Bahia, H. U., \& Davies, R. (2011). Effect of crumb rubber modifiers (CRM) on performance-Related properties of asphalt binders. The Pennsylvania Transportation Institute, USA, 414-438.

Battey, R, L. (2004). Performance of polymer modified Hot Mix Asphalt pavements-an extended evaluation. Mississippi department of transportation, No.FHWA/MS-Dot-Rd-04-141, USA.

Becher, Y., Mendez, M. P. \& Rodriguez, Y. (2001). Polymer modified asphalt. Vision technologica, 9(1), Venezuela. 
Box, G. E. P., \& Hunter, J. S. (1956). Multi-Factor experimental designs for exploring response surface. Institute of Statistics, USA.

Brule, B., \& Gazeau, S. (2006). Characterization of rheological and thermal behavior of asphalt cements modified by ethylene copolymers. Enterprise Jean Lefebvre, France, 1289-1295.

Calrecovery and International Environmental Technology Center (IETC). (2005). Solid waste management. United Nations Environment Programme (UNDP).

Caltrans. (2003). Asphalt rubber usage guide. State of California Department of Transportation, USA, 5-47.

Caltrans. (2005). Use of scrap tire rubber. State of California Department of Transportation, USA, 12-34.

Caltrans. (2006). Asphalt rubber usage guide. State of California Department of Transportation, USA, 6-13.

Carlson, D. D., \& Zhu, H. (1999). Asphalt rubber-an anchor to crumb rubber markets. Rubber pavements association. State of Arizona, USA, 4-27.

Chaaban, F. B. (2008). Arab environment: Future Challenges-Air quality. Abu Dhabi Environment ministry, UAE, 13-14.

Coomarasamy, A., \& Hesp, S. A. (1997). Performance of scrap tire rubber modified asphalt paving mixes. Rubber division-American chemical society, Paper No.95, State of Ohio, USA $2-9$.

Dakhil, I. H. (2004). Absorption of sulfur dioxide by urea. (M.Sc. Thesis), University of Technology, Iraq.

Daranga,C. (2005). Characterization of aged polymer modified asphalt cements for recycling purposes. (Ph.D. Thesis), Department of Chemistry, Agricultural and mechanical college, Louisiana state university, USA.

Defense Logistics. (2005). Action needed to improve the availability of critical items during current and future operations. Congressional Committees, USA, 60-61.

Engle, E., \& Mujeeb, M. (2002). Evaluation of recycled rubber in asphalt cement concrete-field testing. Iowa Department of Transportation, USA, 14-20.

Fayadh, S. S. (1987). Hydrated lime and rubber as additives in asphalt paving mixtures. (M.Sc. Thesis), Iraq.

Fernandes, M. R., \& Forte, M. M. (2008). Rheological evaluation of polymer-modified asphalt binders. Materials research, 11(3), 381-386. http://dx.doi.org/10.1590/S1516-14392008000300024

Fonts, L. P., \& Triches, G. (2008). Comparison between asphalt rubber and conventional mixtures in overlay design. Eurasphalt and Eurobitume congress, Denmark, 2-9. 
Fonts, L. P., \& Triches, G. (2009). Fatigue laws for Brazilians asphalt rubber mixtures obtained in 4 points bending test. University of Minho, Portugal, 5-12.

Ghaly, N. F. (2008). Effect of sulfur on the storage stability of tire rubber modified asphalt. World Journal of Chemistry, 3(2), 42-50, Egypt.

Glandt, E. D., Klein, M. T., \& Edgar, T. F. (2001). Optimization of chemical processes, USA, $35-40$.

Hainian, W., Zhengxia, D., \& Lian, L. (2013). Analysis on fatigue crack growth laws for crumb rubber modified (CRM) asphalt mixing. Journal of Construction and Building materials, 47, 1342-1349. http://dx.doi.org/10.1016/j.conbuildmat.2013.06.014

Hasan, M. K. (2008). Guide for Hot Mixes designs. National center for construction laboratories and research (NCCLR), part/6 laboratory, Iraq.

Hassan, N. B. (2004). Performance of hot mix asphalt using fine crumb rubber. (M.Sc. Thesis), Universiti Teknology, Malaysia.

Heerden, J. V. (2009). Origins, Manufacture and handling of bitumen (asphalt cement). Road pavement forum, Pretoria, 2-55.

Heitzman, M. A.(1992). Design and construction of asphalt paving materials with crumb rubber modifier. Federal highway administration, FHWA-SA-92-022, USA.

Huang, Y., Bird, R., \& Heidrich, O. (2007). A review of the use of recycled solid waste materials in asphalt pavements. University of Newcastle, UK, 6-14.

Japan Cooperation Center, Petroleum. (2013). Guide on asphalt paving technology. Japan.

Khaldoun, M. „Shatanawi, D., \& Szabolcs, B. (2013). Effects of furfural activated crumb rubber on the properties of rubberized asphalt. Journal of Construction and Building materials, 23, 96-103. http://dx.doi.org/10.1016/j.conbuildmat.2011.06.041.

Khodary, F. (2010). Evaluation of fatigue resistance for modified asphalt concrete mixture based on dissipated energy concept. Technische University, Denmark.

Kumar, P., \& Mehndirtta, H. C. (2009). Rheological properties of crumb rubber modified bitumen-A lab study. Journal of scientific and industrial research, 68, 812-816, India.

Kurtis, K. (2004). Asphalt and asphalt concrete. Georgia institute of technology, USA, 2-40.

Lazic', R. Z`. (2004). Design of Experiments in Chemical Engineering. USA, 23-30.

Liseane, P. T., \& Jorge, C. P. (2013). Assessment of the digestion time of asphalt rubber binder based on microscopy analysis. Journal of Construction and Building materials, 47,431-440. http://dx.doi.org/10.1016/j.conbuildmat.2013.05.087.

Maryland department of the environment. (2006). Maryland scrap tire program. USA, 1-2.

Maryland department of the environment. (2008). Maryland scrap tire-Annual report. USA, 6-23. 
Mogawer, W. S. (2011). Performance characteristics of asphalt rubber mixtures. University of Massachusetts Dartmouth.

Mohammed, A. A., \& Omar, H. (2009). Rheological properties of crumb rubber-modified bitumen containing antioxidant. Arabain Journal for science and engineering, 34(1B), Malaysia.

Mohammed, T. J., \& Barbooti, M. M. (2011). Effect of pyrolysis conditions on pyrolytic of scrap tires under reduced pressure. University of Technology, Iraq, 1-12.

Montgomery, D. C. (1976). Design and analysis of experiments. Georgia Institute of Technology, USA, 42-70.

Najim, K. B. (2008). Mechanical properties of fiber waste tire concrete. Engineering college, Al-Anbar University. IJCE, 12, 124-137.

National center for pavement preservation. (2009). Polymer modified asphalt emulsion-composition, uses and specification for surface treatments. USA, 2-16.

Neto, S. A., \& Farias, M. M. (2009). Influence of digestion time on the mechanical properties of gap-graded hot mixes produced with asphalt rubber binders. Asphalt rubber magazine, Brazil, 355-366.

Nevada Automotive Test Center. (2004). Increasing the recycled content in new tires. Integrated waste management board, state of California, USA, 10-50.

Odian, G. (2004). Principles of polymerization. City university of New York (4th ed.), USA, 53-78.

Office of solid waste and emergency response. (1991). Markets for scrap tires. Environmental Protection Agency, USA, 6-23.

Office of solid waste and emergency response. (2006). Scrap tire cleanup guidebook-a resource for solid waste managers across the United states. Environmental Protection Agency, USA, 7-41.

Office of solid waste and emergency response. (2007). U.S.-Mexico border scrap tire inventory-summary report. Environmental Protection Agency, USA, (2007).

Pahlken, A., \& Essadiqi, E. (2005). Scrap tire recycling in Canada. Canmet materials technology laboratory, report MTL2005-8(CF), Canada, 2-16.

Papaiannakis, A. T., \& Loughheed, T. J. (1995). A review of crumb rubber modified asphalt concrete technology. Washington state university, USA, 13-60.

Parilti, N. B. (2010). Treatment of a petrochemical industry wastewater by a solar oxidation process using the Box-Wilson experimental design method. Ekoloji.2010.772, Turkey.

Partanen, J. E. (2006). Synthetic asphalt recycled tire rubber emulsions and processes for making them. U.S. Patent 11/321361. 
Pavlovich, R. D., \& Morris, G. R. (1978). Utilization of recycled tire rubber as an additive to asphalt cement. International conference on the use of By-Products and Waste in civil engineering, France, 3-12.

Peters, M. S., Timmerhaus, K. D., \& West, R. E. (2003). Plant design and economics for chemical engineers. USA, 4-18.

Putman, B., \& Amirkhanian, S. (2006). Crumb rubber modification of binders: Interaction and particle effects. University of Clemson, USA.

Ravindran, A., Ragsdell, K. M., \& Reklaitis, G. V. (2006). Engineering optimization, methods and applications. USA, 4-32.

Reisman, J. I. (1997). Air emissions from scrap tire combustion. U.S. Environmental Protection Agency, EPA-600/R-97-115, USA.

Schulz, Owen, G., Klemmensen, \& Frederick, D. (1999). Asphalt cement modification. U.S. patent 5902852.

Shuart, Jr., Kingsley, R., Presley, \& Lynn, J. (2008). Modified asphalt compositions, U.S. patent 7439286.

Shutang, L., \& Weidong, C. (2009). Variance analysis and performance evaluation of different crumb rubber modified (CRM) asphalt. Journal of Construction and Building materials, 23, 2701-2708. http://dx.doi.org/10.1016/j.conbuildmat.2008.12.009

Solari, S. (2006). Effects of recycled asphalt shingle on the rheological and molecular composition properties of asphalt cement. (M.Sc thesis), University of Ferdowsi, Iran.

Sousa, J. B., Pais, J. C., \& Saim, R. (2000). The effect of mode of loading on the comparison between asphalt rubber and traditional hot mixes laboratory performance. Asphalt rubber 2000 conference, 259-271, Portugal.

State Organization of Roads and Bridges (S.O.R.B.). (2003). Standard Specification for Roads and Bridges. Republic of Iraq, Ministry of Housing and Construction, Department of Design and Studies, Baghdad, 12-52.

Sullivan, J. P. (2006). An assessment of environmental toxicity and potential contamination from artificial turf using shredded or crumb rubber. Turfgrass producers international, USA, 16-24.

Wallage, H. A., \& Martin, J. R. (1967). Asphalt pavement engineering. USA, 23-54.

Way, G. B., \& Kaloush, K. E. (2011). Asphalt rubber standard practice guide. Rubber pavements association, State of Arizona, USA, 2-14.

Williamson, P. (2006). Use of reclaimed tyre rubber in asphalt. Transit New Zealand, 11-24.

WMA Technologies. (2010). Federal highway administration (FHWA). U.S. Department of Transportation, USA, 1-2. 


\section{Macrothink}

Journal of Environment and Ecology

ISSN 2157-6092

2013, Vol. 4, No. 2

Zaman, A. A., \& Frickem, A. L. (1995). Rheological properties of rubber modified asphalt.

Journal of transportation engineering, 121(6), 461-466.

http://dx.doi.org/10.1061/(ASCE)0733-947X(1995)121:6(461)

\section{Glossary}

\begin{tabular}{|c|c|c|}
\hline Symbol & Description & $\underline{\text { Unit }}$ \\
\hline AASHTO & American Association of State Highway and Transportation Officials & - \\
\hline ASTM & American Society for Testing and Materials & - \\
\hline $\mathrm{AC}$ & Asphalt Cement & gm \\
\hline AR & Asphalt Rubber & Ton \\
\hline $\mathrm{F}_{\mathrm{m} 1}$ & Constant factor for the instrument Marshall stability & - \\
\hline CRM & Crumb Rubber Modifier & gm \\
\hline HMA & Hot Mix Asphalt & Ton \\
\hline MAC & Modified Asphalt Cement & gm \\
\hline$Y_{\text {Real }}$ & Penetration response real value & $\mathrm{mm}$ \\
\hline VFA $(\%)$ & Percentage of voids filled with asphalt cement & - \\
\hline $\operatorname{VMA}(\%)$ & Percentage of voids in the mineral aggregate & - \\
\hline VTM $(\%)$ & Percentage of voids in the total mix (air voids) & - \\
\hline $\mathrm{G}_{\text {Real }}$ & Softening response real value & ${ }^{\circ} \mathrm{C}$ \\
\hline S.O.R.B. & State Organization of Roads and Bridges/Iraq & - \\
\hline WCR & Waste Car tire Rubber & gm \\
\hline WTR & Waste Truck tire Rubber & gm \\
\hline
\end{tabular}

